\title{
The Effort in Developing The Management of Quality Assurance in The University
}

\author{
Ulian Barus \\ Education Management Study \\ Program \\ School of Postgraduate Studies \\ Universitas Negeri Medan,Indonesia \\ ulian_barus@yahoo.com
}

\author{
Zainuddin \\ Education Management Study \\ Program \\ School of Postgraduate Studies \\ Universitas Negeri Medan, Indonesia
}

\author{
Harun Sitompul \\ Education Management Study \\ Program \\ School of Postgraduate Studies \\ Universitas Negeri Medan, Indonesia
}

\begin{abstract}
Quality assurance can be interpreted as qualitative and continuous change progressively increased. On that issue, the quality of university graduates should have the ability not only the superiority but also has a broader scope of area involving: knowledge, ability to always learn, toughness in intellectuality, work ability in an organization or modern institution, interpersonal skills, and also the ability to communicate effectively and persuasively. Of course, in its implementation is very influenced by the local environment, in this situation and the condition is the higher education itself. The significance of local influence has been previously identified by Hoy it has a great opportunity to color the quality assurance model and its characteristics, so it enables both the growth of the quality management model on its own way and the type of evaluation towards the progress achievement. Quality management must be supported by good academic atmosphere, so the effort of academic quality improvement can run faster and more effective. This effort can be done through the development of a good and conducive academic culture by inviting all academic community to jointly improve the better process of learning and education based on quality commitment desired and expected by academic community.
\end{abstract}

Keywords: quality assurance, management, University

\section{INTRODUCTION}

University is a higher education institution playing an important role in the nation building. Universities have risen educated and intellectuals people who organize the life of the nation towards greater purposes. In achieving them, universities need a comprehensive arrangement on the management institutions and management itself. The determinant factor determining the quality of a higher education lies on the management of the university. Infrastructure, facilities and human resources in a university, are ineffective if they are not managed through the management of universities.

Universitas Muslim Nusantara (UMN) Al Washliyah forming a quality assurance management unit in increasing its existence is as one of the Private Universities in Medan.Fraser
(2015) stated that the implementation of a quality assurance unit in an institution will have a positive effect on each goal achievement of each unit in each institution promising superior quality.Data from Al Washliyah Foundation in North Sumatra, December 2017 shows that the number of UMN Al Washliyah students is greater than Universitas Al Washliyah, with a comparison of the number of students 8210: 2475 . Management improvement of UMN Al Washliyah is also seen by participating 22 professors and doctors, 22 lecturers having S-3 education program and managing 17 study programs including the newly ones Master of Law and Master of English Studies.

In the management of UMN Al Washliyah Medan, quality assurance is not limited to maintain academic quality but also the ideological quality of UMN Al Washliyah (which has an Islamic nuance). That is why quality assurance in UMN Al Washliyah is not enough to produce graduates who are academically superior, but also must be Islamic. In addition, maintaining the quality of Islamic ideology is used as a distinguishing character with graduates from other private universities. The results of the research by Soria and Jordan (2014); Mozghan et al (2011); Tessema, Kathryn and Wei (2012); and Kayani (2011) concluded that the quality of graduates greatly influences the perception of the wider community towards the achievement of institutions. The higher the quality of graduates (having knowledge, morality, and ethics as a religious person) further increases the desire of the community to employ the institutional graduates.

Quality assurance at UMN Al Washliyah is based on uniqueness accommodating the basic elements of existing quality assurance very necessary. The discovery of quality assurance is important sinceit has not been formulated, and also the basic elements of quality assurance have so far developed in UMN Al Washliyah. Specific basic elements of quality assurance in UMN Al Washliyah are for example, the implementation of Islamic and AlWashliyahsubjects andit is a must for students to take a recitationfor at least 8 meetings as ideological quality assurance.

A research done by Earnest (2011) shows that a quality improvement model through curriculum engineering, namely competency based engineering curricula arises due to changes 
and quality for inability of graduates to take them to the workforce. Murray (2012: 1) states that in the context of external relations, quality assurance is functioned as a tool used by higher education to ensure that graduates can be accepted in other institutions as a public accountability for the community at the offer of educational programs.

Some reasons why UMN Al Washliyah must focus its attention on quality are to schedule quality assurance as something that must be done immediately and strived continuously. This is also stated by Mondie (2008:5), namely:

- Great attention about the amount of public funds absorbed in the administration of higher education to the extent that the allocation is supposed to be for other sectors by the community is allowed to support the implementation of education.

- Attention is focused on future economic competition and therefore there is a need for qualified and highly competent workers in post-industrial societies.

- The problem of monitoring the input and output-process of higher education in a management system that is increasingly innovative and fast should not be hampered by the shrinking of resources both human and natural resources.

- There is an internationalization movement of the Higher Education which is increasingly strong in the application of assessment and measurement standards for basic abilities and similarities in professional academic qualifications, especially for graduates using international standards and those recognized by the world. Ranking of universities by the international community shows that quality is increasingly prioritized.

- The commitment in several places or countries to develop public services that is more efficient, more responsive in accordance with the needs of customers.

Views, beliefs, and satisfaction are now used as the key to the development of UMN Al Washliyah in real or disguised, starting to develop quality assurance, especially in guaranteeing qualified education services. Without qualified management of quality assurance, it is feared that UMN Al Washliyah will decrease its productivity level. Jennings (2012) and Tomlinson (2014) state that there is no guarantee of Higher Education to survive tomorrow if it does not pay any attention to quality. This indicates that every university must plan and supervise the implementation of quality in each section / work unit.

In the perspective of education management, Foskett and Jacky (2013) stat that quality assurance has significant significance because it is specific and its existence is highly dependent on the system where the quality assurance is located, so that it could be different between designs planning and approach applied.In this case quality assurance as classified by Ellis can be positioned in a latent position, radical or as development. The position of quality assurance is strongly influenced by how situational the institution itself is. Robbins (2011: 24) and Bush (2013: 57) describe that in the system level, implementation of institutional policies such as quality assurance always involves organizational culture, institutional structure and organizational work structuring so that in the same policy the institution may be different.

Adina (2017: 2) asserted that quality assurance in Higher Education is very important considering the educational target is not only for academics but also whole aspects. Likewise in the higher education environment in UMN Al Washliyah has both scientific character and religious affinity, namely Kealwashliyahan. The issue of quality assurance is still considered new and has not been developed intensively and seriously. Stevenson (2014: 9) emphasized that newly developing universities tend to strengthen the capacity of the organization, while the quality assurance mechanism is less noticed.

The focus of this research was on the discovery of the quality assurance of UMN Al Washliyah. The specialization of this study is because assumed that every quality assurance of UMN Al Washliyahis unique due to different elements assured, the readiness of lecturers, the process taken, and different independence in the implementation of quality assurance. The research focus is divided into three sub-focus namely: (1) elements that must be subject to quality assurance at UMN Al Washliyah Medan; (2) quality assurance process at UMN Al-Washliyah Medan; and (3) quality assurance model at UMN Al Washliyah Medan.

\section{REVIEW OF LITERATURE}

\section{A. Higher Education Management}

Management is a word that is used daily so that it is assumed that everyone knows its meaning. Management as formulated by Jones (2010:5) is the planning, organizing, leading and controlling of resources to achieve organizational goals effectively and efficiently. The same thing by adding decision making, Dubrin (2010: 5) gives an understanding of management a process of using organizational resources to achieve organizational goals through the functions of planning, and decision making, organizing, leading and controlling.

\section{B. Meaning of Quality in the Context of Quality Assurance in Higher Education}

Quality is defined as a standard and excellence, so that the main element of quality in quality assurance is understood as a process of certainty that there is a specific standard and is continuously pursued for a superior product or service. Ellis (2013: 1) states that thinking about the quality in learning importantly is always related to the satisfaction of consumers, in this case the primary customer is a student.

According to Arcaro (2015: 55), "Quality is seen as a process so quality is defined as a structured process for increasing the output produced, thus the end result of quality is the product." The Directorate General of Indonesian Higher Education summarized in the Guidelines for Higher Education Quality Assurance (2003: 9) mentions that an organization of education in Higher Education is seemed qualified if: (1) the university is able to establish and realize its vision through the 
implementation of its mission (deductive aspect); and (2) it is able to meet stakeholder needs, especially the interests of students and industry (inductive aspects), namely: community needs, workforce needs, and professional needs.

The above characteristics show that the higher education institution absolutely having relations with stakeholders to measure the quality of higher education services that must be held. In this case the external criteria used as a grip is whether in increasing the quality. Referring to this characterization, there is an assertion that the implementation of quality assurance requires a paradigm shift about the standard, namely not only replacing the whole thing, but also the piecemeal change. In other words, an educational activity is seen as quality if higher education is able to provide the best learning opportunities that can be used to teach students to achieve goals.

In the effort to develop higher education, programs for structuring the education system, improving quality and relevance and expanding and spreading access to higher education are carried out. Each operational program is equipped with indicators of success so that it is more clearly benchmarked for its achievement. Furthermore the quality development program in the higher education environment is given schematically in the table below.

TABLE I. Operational Program For The Development Of Higher Education Quality

\begin{tabular}{|c|c|c|}
\hline No & Operational Program & Indicator of Success \\
\hline 1. & $\begin{array}{l}\text { Administration System of } \\
\text { Higher Education } \\
\text { - Application of new } \\
\text { paradigms: autonomy, } \\
\text { accountability, quality, } \\
\text { accreditation, and self- } \\
\text { evaluation } \\
\text { - Block grant funding } \\
\text { mechanism } \\
\text { - Higher Education self- } \\
\text { evaluation } \\
\text { Improvement } \\
\text { - Higher Education } \\
\text { strategic planning } \\
\text { Improvement }\end{array}$ & 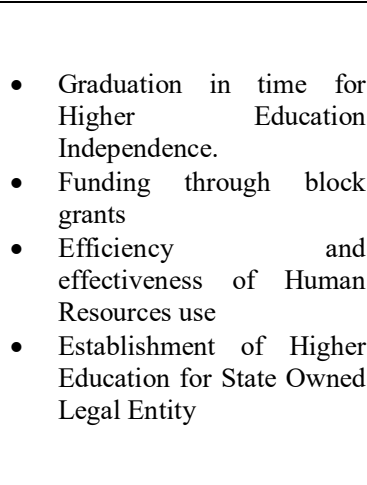 \\
\hline 2. & $\begin{array}{l}\text { Quality and Relevance } \\
\text { Improvement } \\
\text { - Qualified education } \\
\text { improvement for } \\
\text { lecturers. } \\
\text { - Partnership and } \\
\text { international } \\
\text { benchmarking. } \\
\text { - Capacity and quality } \\
\text { improvement of study } \\
\text { programs in accordance } \\
\text { with global } \\
\text { competition. in } \\
\text { Quality improvement } \\
\text { and research activities. } \\
\text { activities and quality } \\
\text { improvement in } \\
\text { community services }\end{array}$ & $\begin{array}{l}\text { - Percentage of S2/S3- } \\
\text { qualified lecturers } \\
\text { - The proportion of exact/ } \\
\text { non-exact students. } \\
\text { - Achievement and position } \\
\text { of the National higher } \\
\text { education on an } \\
\text { international scale. } \\
\text { - Productivity of scientific } \\
\text { works, publications, } \\
\text { patents and intellectual } \\
\text { property rights of } \\
\text { - Higher Education } \\
\text { Contribution to community } \\
\text { development }\end{array}$ \\
\hline 3. & $\begin{array}{l}\text { Extension and Examination } \\
\text { of Higher Education Access }\end{array}$ & \\
\hline
\end{tabular}

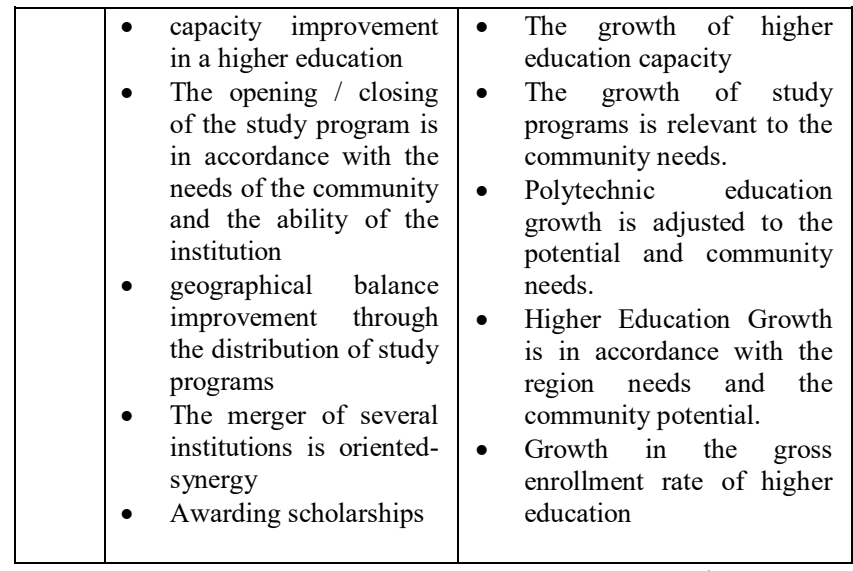

Source: Sukamto, 2012

\section{Quality Assurance Model at UMN Al Washliyah Medan}

The implementation of quality assurance is situational so that there are always various models and emphasis on certain quality assurance elements. In view of quality assurance model at UMN Al Washliyah Medan, the quality profile is prepared by conducting dialogue with the right stakeholders. The formulation of standard quality is categorized into two categories, namely the must-have quality standard category, namely the quality standard, which there should not an offer in the implementation, while the second category is the supposed quality standard. It means that quality standards have the opportunity not to be fulfilled absolutely.

The quality standard is at least applied for three components, namely the quality standard for students which involves service and increasing monitoring of student activities. The second component involves education programs including: quality standards for curriculum development and improvement of the teaching and learning environment. The third component is quality standards for academic staff including: quality of lecturers and improvement of research and publication works.

The processes undertaken are always monitored through quality assessments which are then analyzed to be compared with quality standards. All quality assessment actions aim to obtain a service satisfaction level for the parties. Susan (2013: 43) revealed that quality assurance is designed so that the level of student dropped out getting smaller, because DO level is the indicators of student dissatisfaction and also fitness indicators for the purpose of all processes applied.

The process of implementing quality assurance at UMN Al Washliyah Medan appears to have seen several advantages with two aspects, namely the higher education policy of the Ministry of National Education and the Higher Education Policy of Al Washliyah under Al Washliyah Foundation. The main function of the UMN Al Washliyah as a higher education is to create graduates who are academically reliable and produce cadres and graduates who have the ideology of $\mathrm{Al}$ Washliyah. UMN Al Washliyah as a Higher Education is considered failed if it only produces graduates who are reliable in science but apart from efforts to produce graduates who are both cadres of Al Washliyah and successors of Al Washliyah's charitable endeavors. 
Al Washliyah's quality assurance model requires the necessity of all supporting devices in a good and complete condition. This requirement makes this quality assurance model not easily implemented by UMN Al Washliyah College. The implementation process is as follows:

- Choosing a standard or benchmarking that is used as a reference for quality standards.

- Preparing instruments and conducting audits.

- Conducting an audit of all academic, administrative and alumni components.

- Analyzing audit results in a weakness center identification.

- Formulating an action plan for perfection.

- Running the action agenda while collecting evidence of improvement.

- Reviewing and documenting for institutional development needs.

\section{Higher Education Philosophy of UMN Al Washliyah Medan}

According to the Qoidah (implementing regulations of Higher Education Al Washliyah) part 1 Article 2, UMN Al Washliyah is a higher education institution in Al Washliyah organization tasked with organizing higher education according to Islam guidance, then in the provisions of Article 3 further explained that the UMN Al Washliyah as a Higher Education has Islamic principles which are based on the Qur'an and the Sunnah.

The final goal of implementing Al Washliyah as a Higher Education is not only limited to strengthening the academic side but also producing graduates. The assertion of this final goal was wrtitten in the formulation of the Higher Education of Al Washliyah which was stated in Article 4, Qidah of the UMN Al Washliyah as a Higher Education in 1999 which was formulated as follows: (1) preparing students to become faithful Muslim scholars and devoted to Allah SWT, noble deeds who have academic and / or professional abilities and charity towards the realization offair and prosperous society which are blessed by Allah SWT; and (2) developing and disseminating science, technology and art in order to promote Islam and improve human welfare.

In the Statute explanation, it was confirmed that the purpose of UMN Al Washliyahis as follows:

- Graduate Muslim scholars who have: (1) the depth of Islamic and high religious value, (2) academic and / or professional ability, and (3) the soul of devotion to the realization of an Islamic society and improving human welfare,

- Disseminate science, technology and art in order to promote Islam and the benefit of mankind.

The implementation of UMN AlWashliyah College Medan, the two goals must be elaborated in the curriculum and other devices (lecturers and staff) in a well plan. This assertion provides a policy line that the quality must be achieved is not just one, not only achieving academic quality but also the religiosity of students studying in the environment of $\mathrm{Al}$ Washliyah.
In an effort to anticipate new developments, within the UMN Al Washliyah Medan is fully aware of the responsiveness to the latest changes, especially in external conditions. New changes must be responded wisely, so that in its implementation it has now emerged a new vision of UMN Al Washliyahas a Higher Education. The vision of UMN Al Washliyah which is a formulation of response to recent external developments shows that the new vision of UMN Al Washliyah includes philosophical foundation, Islamic ethical foundation and an operational basis for the implementation.

\section{CONCLUSION}

Standard of quality assurance management is carried out well, so greater autonomy for private universities, especially for Al Washliyah UMN is more meaningful. For that reason, the existence of a quality assurance institution at UMN AlWashliyah does not only become a "signboard" but actually functions accordance with its duties and roles. An active quality assurance institution strives to achieve a greater responsibility, greater quality assurance, and greater accountability for its institutions, not to tend to seek faults of others in its institutions. Even when Greater autonomy implemented effectively and efficiently has an impact on the development of study programs and curricula that reflect the community needs. Greater responsibility means that UMN Al Washliyah must be responsible to all stakeholders and customers (representing all users).

Quality management must be supported by good academic atmosphere so that efforts to improve academic quality can run faster and more effectively. A good academic atmosphere is born when it is supported by a holistic awareness of the entire academic community. This effort can be done through the development of a healthier and more conducive academic culture by inviting them to jointly improve the better learning and education process based on the quality commitment desired and expected by all academic community.

\section{REFERENCES}

[1] Adina, Bloom Lewkowicz, Teaching Emotional Intelligence, Strategies and Activities for Helping Student Make Effective Choices. California: Corwin Press, 2017.

[2] Arcaro, S. Jerome, Quality Education, an Implementation. Florida: St Lucie Press, 2015.

[3] Bush, Tony, Theories of Educational Leadership and Management. London: Sage Publications Ltd, 2013.

[4] Direktorat Jenderal Pendidikan Tinggi, Pedoman Penjaminan Mutu Pendidikan Tinggi. Jakarta: Dikti, 2003.

[5] Dubrin, Andrew J, Essensials of Management. Ohio: South-Western Publishing Co., 2010.

[6] Earnest, Joshua, "Competency-Based Engineering Curriculum, An Innovative Approach," in International Conference on Engineering Education. Oslo. August 6-10, 2011.

[7] Ellis, Roger, Quality Assurance for University Teaching. Bristol: OpenUniversity, 2013.

[8] Foskett, Nick and Lumby, Jacky, Leading and Managing Education: International Dimensions. England: University of Leicester, 2013.

[9] Fraser, Kym. Edt, Education Development and Leadership in Higher Education: Developing an Effective Institutional Strategy. New York: Routledge Falmer, 2015. 
[10] Jennings, Jasson, It'sNot The Big That Eat The Small... It's The Fast That Eat the Slow, How to Use Speed as A Competitive Tool in Business. New York: Harper Business, 2012.

[11] Jones, Gareth R., Contemporary Management, Second Edition, United States of America: The MC Graw-Hill Companies, Inc., 2010.

[12] Kayani, Muhammad Munir., Morris, David,Azhar, Muhammad, and Kayani, Kayani. 2011. "Analysis of Professional Competency Enhancement Program of Nahe On The Performance of College Teachers" on International Journal of Business and Social Science, Vol. 2 No. 18; October 2011

[13] Mondie, G.C., The Debates about Higher Education in Britain and USA, Studies in Higher Education, 2008.

[14] Mozhgan, Amirianzadeh., Jaafari Parivash, Ghourchean Nadergholi, and Bahram Jowkar, "Student Leadership Competencies Development" on Procedia Social and Behavioral Sciences, 2011, pp 1616-1620.

[15] Murray, F.B, New Directions for Higher Education, How Accreditation Influences Assessment. New York: Jossey-Bass, 2012.

[16] Olssen, Mark, Education Policy: Globalization, Citizenship and Democracy. London: Sage Publications, 2004.

[17] Robbins, Stephen P, Organization Behavior. New Jersey: Prentice Hall Intrnational Inc., 2011.

[18] Soria, Krista M. and Troisi, Jordan, "Internationalization at Home Alternatives to Study Abroad: Implications for Students' Development of Global, International, and Intercultural Competencies," on Journal of Studies in International Education, Vol. 18(3), pp 261-280, 2014.

[19] Stevenson, Michael, "University Governance and Autonomy, Problem in Managing access, Quality and Accountability". on Seminar on Higher Education, Nali, 28 April 2014.

[20] Sukamto, Quality Assurance dan Pengembangannya di PerguruanTinggi Al Washliyah. Yogyakarta: University Press, 2012.

[21] Susan, Storey, Total Quality Management Through BS 5750 a Case study. Bristol PA USA: Frost Road Suite 101, 2013.

[22] Tessema, Mussie T., Kathryn Ready, and Wei-Choun "William" Yu, "Factors Affecting College Students' Satisfaction with Major Curriculum: Evidence from Nine Years of Data", onInternational Journal of Humanities and Social Science, Vol. 2 No. 2 [Special Issue January 2012.

[23] Tim Penjaminan Mutu Universitas Muslim Nusantara Al-Washliyah Medan, Spesifikasi dan Kompetensi Program Studi. Medan: UMN AlWashliyah, 2016.

[24] Tomlinson, Harry,Educational Leadership: Personal Growth for Professional Development. London: SAGE Publications Ltd., 2014. 